\title{
HCN Channels: New Therapeutic Targets for Pain Treatment
}

\author{
David Ramírez ${ }^{1}$ (1) , Rafael Zúñiga ${ }^{2}$, Guierdy Concha ${ }^{2}$ and Leandro Zúñiga ${ }^{2, *}$ \\ 1 Instituto de Ciencias Biomédicas, Universidad Autónoma de Chile, 5 Poniente 1670, Talca 3460000, Chile; \\ damach.david@gmail.com \\ 2 Centro de Investigaciones Médicas, Programa de Investigación Asociativa en Cáncer Gástrico, \\ Escuela de Medicina, Universidad de Talca, Talca 3460000, Chile; rafaelzunigah@gmail.com (R.Z.); \\ guierdy@gmail.com (G.C.) \\ * Correspondence: lzuniga@utalca.cl; Tel.: +56-71-2418821
}

Received: 17 July 2018; Accepted: 18 August 2018; Published: 21 August 2018

\begin{abstract}
Hyperpolarization-activated cyclic nucleotide-gated (HCN) channels are highly regulated proteins which respond to different cellular stimuli. The HCN currents $\left(\mathrm{I}_{\mathrm{h}}\right)$ mediated by HCN1 and $\mathrm{HCN} 2$ drive the repetitive firing in nociceptive neurons. The role of $\mathrm{HCN}$ channels in pain has been widely investigated as targets for the development of new therapeutic drugs, but the comprehensive design of HCN channel modulators has been restricted due to the lack of crystallographic data. The three-dimensional structure of the human HCN1 channel was recently reported, opening new possibilities for the rational design of highly-selective HCN modulators. In this review, we discuss the structural and functional properties of $\mathrm{HCN}$ channels, their pharmacological inhibitors, and the potential strategies for designing new drugs to block the HCN channel function associated with pain perception.
\end{abstract}

Keywords: $\mathrm{HCN}$ channels; $\mathrm{HCN}$ structure; $\mathrm{HCN}$ blockers; $\mathrm{HCN}$ channels expression; pain condition

\section{Introduction}

\section{HCN Channels Structure and Function}

Hyperpolarization-activated cyclic nucleotide-gated $(\mathrm{HCN})$ channels are members of the voltage-gated pore loop channel superfamily [1-3], and are also related to the cyclic nucleotide-gated (CNG) channels as well as to the voltage-dependent $\mathrm{K}_{\mathrm{V}} 10-\mathrm{K}_{\mathrm{V}} 12$ channels [4] (Figure 1A). Besides the voltage-dependent gating, HCN channels are activated by intracellular cyclic nucleotides $[5,6]$, including guanosine- $3^{\prime}, 5^{\prime}$-cyclic monophosphate (cGMP) and adenosine- $3^{\prime}, 5^{\prime}$-cyclic monophosphate (cAMP), while the modulation of $\mathrm{I}_{\mathrm{h}}$ is similar for both cyclic nucleotides, with the same efficacy at least in mammalians, the apparent affinities of $I_{h}$ are 10-100 fold higher for cAMP than for cGMP [7]. Hyperpolarization-activated cyclic nucleotide-gated channels are integrated by four subunits that together form a central pore. Each subunit contains a voltage-sensor domain and a pore domain contributing to the central pore [8]. However, this cyclic nucleotide modulatory effect depends on each HCN subunit $[9,10]$, with the cAMP sensitivity higher for HCN2 and HCN4, weaker in HCN1, and absent in HCN3 [11,12]. The cGMP has a similar efficacy to cAMP, but with a lower apparent affinity [13].

The cAMP modulation, in HCN channels, is generated by a direct binding to the intracellular cyclic nucleotide binding domain (CNBD) located at C-terminal. This binding leads to accelerated activation kinetics and to a shift of the conductance voltage curve toward positive voltages (up to $20 \mathrm{mV}$ ) [1-3,5]. Additionally, the open probability (Po) of HCN channels can be increased by the cAMP 
binding, but unlike CNG channels, the cyclic nucleotides are not a prerequisite for channel opening [4]. At strong hyperpolarization, two occupied binding sites with cAMP are sufficient to generate the maximum Po $[8,14,15]$, and at least two liganded subunits in trans positions are required to maintain the activation [8].

Moreover, in HCN channels the voltage dependence goes in opposite directions to the classical voltage-dependent ion channels, which opens with a depolarized stimulus. Hyperpolarization-activated cyclic nucleotide-gated channels are closed to a depolarized stimulus and opened to the membrane hyperpolarization [1-3].

In mammals, four HCN isoforms have been identified to encode for the subunits HCN1 to HCN4 [8]. To form a functional channel, HCN subunits (HCN1-4) need to assemble as tetramers. The HCN channels are able to form homo- or heterotetrameric complexes, generating channel subtypes with distinct biophysical properties [16]. Thus, each HCN subunit can be self-assembled in a homomeric architecture, and, excluding HCN2 and HCN3, all dual combinations of HCN subunits co-assemble to form functional heteromeric channels [17]; each subunit comprises six critical transmembrane domains (S1-S6), as well as an intracellular C- and N-terminal (Figure 1B). Similar to other ion channels from the voltage-gated family, the $S 4$ transmembrane domain contains the voltage sensor and comprises several charged amino acids (Arg and Lys residues) [18-21].

Hyperpolarization-activated cyclic nucleotide-gated channels contain a GYG (Glycine-Tyrosine-Glycine) motif that confers the high selectivity for $\mathrm{K}^{+}$ions observed in $\mathrm{K}^{+}$ channels [22]. However, the $\mathrm{Na}^{+} / \mathrm{K}^{+}$permeability ratio in $\mathrm{HCN}$ channels is $\sim 1 / 4$ and also displays a small but significant permeability to $\mathrm{Ca}^{2+}$ ions [23]. For instance, at $2.5 \mathrm{mM}$ of external $\mathrm{Ca}^{2+}$, the $\mathrm{Ca}^{2+}$ current in the native HCN current $\left(\mathrm{I}_{h}\right)$ as well as in the expression system, where channels HCN2 and HCN4 are expressed, is about $0.5 \%[23,24]$. This $\mathrm{Ca}^{2+}$ current of HCN channels is relatively small $\left(0.47 \%\right.$ in HCN2 and $0.6 \%$ in HCN4 channels) compared with the fractional $\mathrm{Ca}^{2+}$ currents in other ion channels, such as the nicotinic acetylcholine receptor (2.5\%) [25], glutamate receptor (10\% for NMDA, N-methyl-D-aspartic acid) [26], AMPA, $\alpha$-amino-3-hydroxy-5-methyl-4-isoxazolepropionic acid/kainate receptors (0.5-5\%) [27], CNG channels (10-80\%) [28], and calcium channels (100\%) [29]. However, this $\mathrm{Ca}^{2+}$ current through $\mathrm{HCN}$ channels may be enough to modulate $\mathrm{Ca}^{2+}$-dependent cellular functions [23,24]. Lee and MacKinnon [4] recently resolved, by cryoelectron microscopy, the three-dimensional structure of the human HCN1 subunit with (Protein Data Bank [PDB] ID: 5U6O) and without (PDB ID: 5U6P) its C-terminus. They reported that the selectivity filter, which contains only two out of four $\mathrm{K}^{+}$binding sites (denoted as 1-4 from the extracellular to the intracellular side), adopts a non-canonical configuration [4], where the $\mathrm{K}^{+}$ion occupies the 3 and 4 sites (Figure 1C, left). This explanation is the main difference between a weak $\mathrm{K}^{+}$-selective filter (HCN1 channel) and a $\mathrm{K}^{+}$-selective filter (e.g., KscA channel) where all sites are occupied by $\mathrm{K}^{+}$(Figure $1 \mathrm{C}$, right). These data may also explain why HCN channels are permeable to different ions, despite the presence of the GYG motif. In the pore of $\mathrm{K}^{+}$selective channels, the four $\mathrm{K}^{+}$binding sites are created by four layers of carbonyl oxygen atoms and one layer of threonine hydroxyl oxygen atoms (Figure 1C, right panel).

A cyclic nucleotide-binding domain (CNBD) is found at the intracellular C-terminus of HCN channels. The CNBD, connected to the S6 transmembrane domain by a C-linker, regulates the $\mathrm{HCN}$ channel activity by facilitating the cyclic adenosine monophosphate (cAMP) binding [30,31] (Figure 1B,D) promoting voltage-dependent activation of $\mathrm{HCN}$ channels [5] (Figure 1D). As indicated previously, HCN subunits present different sensitivity to cAMP. Both HCN2 and HCN4 exhibit high voltage dependence and kinetics of activation to cAMP, which is extremely weak in HCN1 and absent in HCN3 [11,12,32]. The CNBD three-dimensional structure in the presence and absence of cAMP has been solved by crystallography [32] and cryoelectron microscopy [4], and entails six alpha-helices (A-F) and one beta-roll in between the A and B helices [32-37] (Figure 1D). Lee and MacKinnon [4] demonstrated that cAMP binding in the absence of hyperpolarization is insufficient for channel opening; however, the cAMP binding induces 
structural changes, such as the rotation of the inner gate, which may facilitate its opening by changes in the membrane potential.

The HCN channels are widely expressed in peripheral sensory neurons, neurons in the central nervous system [38], and cardiac tissues [2,3,39-41]. The HCN channels generate inward current $\left(\mathrm{I}_{\mathrm{h}}\right)-\mathrm{a} \mathrm{Na}{ }^{+} / \mathrm{K}^{+}$current when the membrane potential is hyperpolarized, producing rhythmic electrical activity in specialized neurons of the brain [39,41,42] and in cardiac sinoatrial node cells [43]. Diverse functions have been attributed to $I_{h}$ currents, including the determination of resting membrane potential (RMP), action potential (AP) firing rate, dendritic integration, and synaptic transmission [44].

Hyperpolarization-activated cyclic nucleotide-gated channel activity plays important roles in behavior and physiological process such as sleep and arousal, learning and memory, and anesthesia [38,45-47]. Misregulation of HCN channel activity has been shown to contribute to neurological and psychological disorders including pain, epilepsy, addiction, and anxiety [48-52].
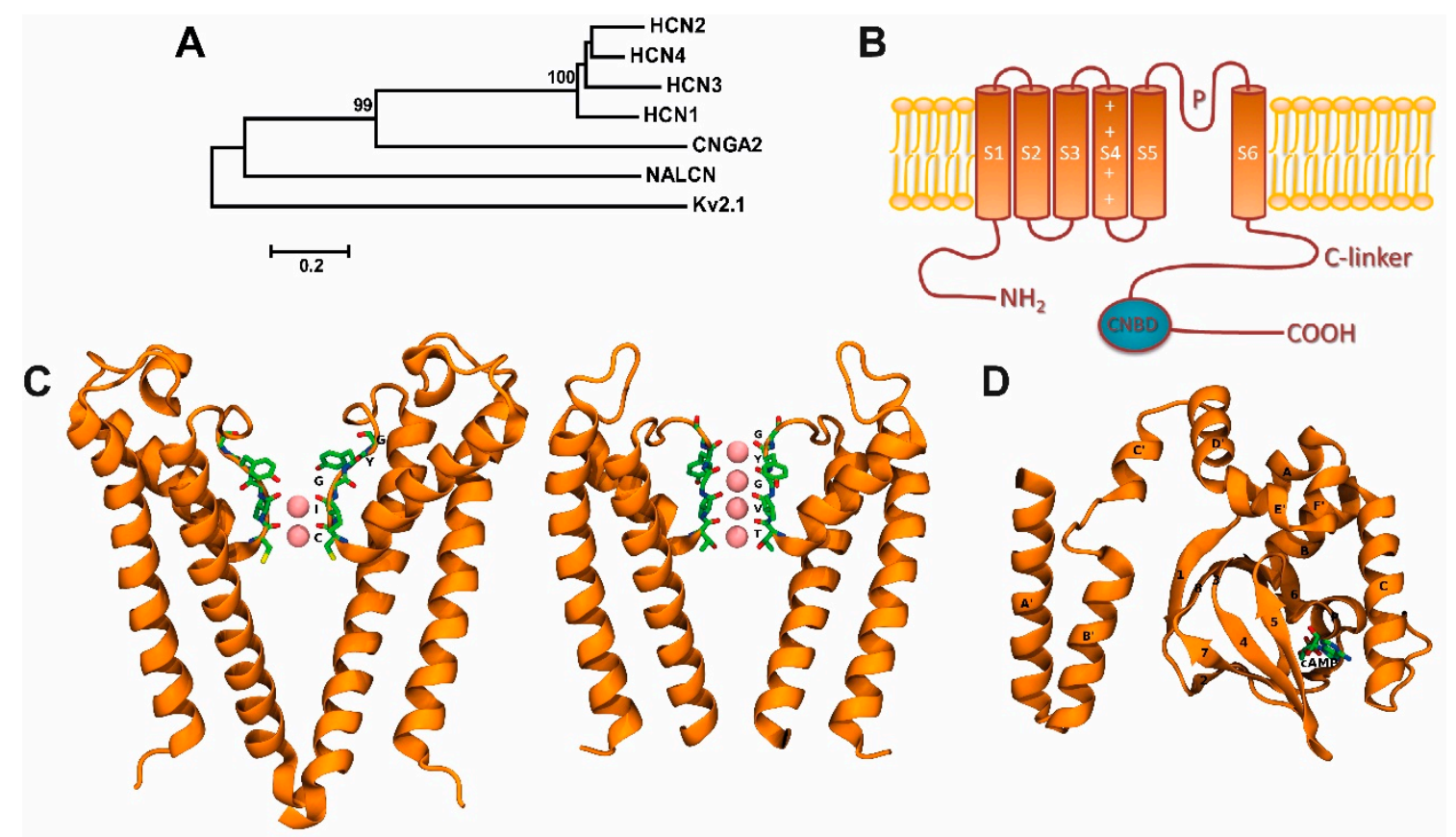

D

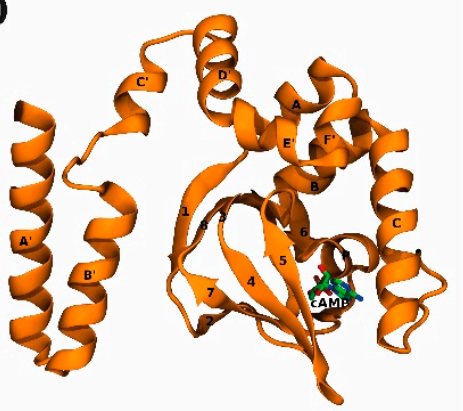

Figure 1. Hyperpolarization-activated cyclic nucleotide-gated $(\mathrm{HCN})$ channels and their two- and three-dimensional structures: (A) Phylogenetic tree showing proteins in the human HCN channel family. It includes selected ion channels of $\mathrm{Kv}$ (voltage-gated $\mathrm{K}^{+}$channel), NALCN (sodium leak channel, non-selective), and CNG (cyclic nucleotide-gated ion channel) families. Phylogenetic analysis was carried out with Molecular Evolutionary Genetics Analysis version 5 (MEGA5) software (www.megasoftware.net.) free of charge. Lines length, scaled below the tree, indicate the relative distance between nodes. Numbers on branches indicate bootstrap values (as a percentage). (B) Topological model proposed for HCN channels. Each subunit has one pore forming domain (P-loops) and six transmembrane domains (denoted S1-S6). The C-terminus of each subunit contains a cyclic nucleotide-binding domain (CNBD) connected to the sixth transmembrane $\alpha$-heli $x$ (S6) via the C-linker. (C) Left, HCN filter structure (Protein Data Bank, PDB: 5U6O [4]) in a ribbon representation, showing a weak $\mathrm{K}^{+}$-selective filter- $\mathrm{K}^{+}$ion occupancy: 3 and 4 sites-. Right, KcsA filter structure (PDB:1K4C), showing a $\mathrm{K}^{+}$selective filter- $\mathrm{K}^{+}$ion occupancy: 1 to 4 sites-. The $\mathrm{K}^{+}$ions in both filters, they are represented as pink spheres. A view of the $\mathrm{K}^{+}$selectivity filter structure is shown on the right (D) cAMP-bound CNBD structure view (PDB:1Q5O [32]) in ribbon representation showing a cAMP molecule in a stick representation. Bothe $C$ and $D$ were prepared using PyMOL software version 2.0 (Schrödinger, LLC. New York, NY, USA). 


\section{HCN Channel Regulation}

The cyclic nucleotide adenosine- $3^{\prime}, 5^{\prime}$-cyclic monophosphate regulates the voltage dependence of HCN subunits [5], and promotes a shift of $10-25 \mathrm{mV}$ in V0.5 in the HCN2 and HCN4 channels [7,10]. In contrast, the V0.5 displayed by HCN1 is only slightly shifted (shift by around 2-7 mV) $[7,10]$, and HCN3 is not modulated by cyclic nucleotides $[7,53]$.

In addition to cAMP, HCN channels are also allosterically regulated by other molecules, such as phosphatidylinositol 4,5-biphosphate, cholesterol, $\mathrm{H}^{+}$, and $\mathrm{Cl}^{-}$ions [31], and modulated by several post-translational modifications, such as phosphorylation (e.g., Src, mitogen-activated protein serine/threonine kinase [p38-MAPK], protein kinase $\mathrm{C}[\mathrm{PKC}]$, and $\mathrm{Ca}^{2+} /$ calmodulin-dependent protein kinase II) [54-57]. For instance, Src shifts the HCN channels voltage dependence, thus accelerating their kinetics [58,59]. Also, p38-MAPK activates HCN channels by shifting the voltage dependence and depolarizing the membrane potential. In addition, PKC inactivates HCN channels. For example, PKC activation by phorbol 12,13-diacetate or $4 \beta$-phorbol 12-myristate 13-acetate downregulates $\mathrm{HCN}$ channels by shifting the voltage dependence to a more negative potential [60-62]. Nowadays, it is not clear how p38-MAPK and PKC modulate HCN channels.

As previously mentioned, cholesterol within lipid rafts can disrupt the HCN channel function since the HCN1, HCN2, and HCN4 subunits expression were downregulated after cholesterol depletion [63].

\section{HCN Channels in the Central Nervous System}

All HCN members (HCN1-4) have been found in central and peripheral nervous systems, where they are associated with synaptic integration, neuronal excitability, and the formation of resting membrane potentials [46]. Neurons highly express HCN channels [44]. In these excitable cells, HCN currents are stated as hyperpolarization currents $\left(\mathrm{I}_{h}\right)$ and can inhibit the passive propagation of excitatory post-synaptic potentials [64-67]. On the other hand, HCN currents are defined as "funny" ( $\mathrm{I}_{\mathrm{f}}$ ) or pacemaker currents in cardiac cells $[30,41,68,69]$. Numerous studies have shown that HCN channels display high mRNA and protein expression levels in central nervous and cardiovascular systems [39-42,68]. For instance, in situ hybridization studies revealed high expression levels of HCN1 subunit in mice's olfactory bulb, cerebral cortex, hippocampus, superior colliculus, and cerebellum [40,42]. The HCN1 subunit expression has also been detected at post-synaptic sites in the basket and Purkinje cells in rats' cerebral cortex [70]. In the mouse brain, the HCN2 subunit is ubiquitously expressed with high expression levels in the olfactory bulb, hippocampus, thalamus, and brain stem [40,42]. In contrast, HCN3 subunit expression levels are very low in the brain [40], whereas the HCN4 subunit is only expressed in the thalamus and the olfactory bulb [40,42].

Immunochemistry studies have shown the localization of various HCN channels in different tissues [39,71]. The HCN1 subunit displays a cortical expression pattern with high expression levels in rats' neocortex, hippocampus, superior colliculus, and cerebellum [39,71], while the HCN2 subunit shows ubiquitous expression in the brain in agreement with Moosmang and Santoro's results [39,71]. On the other hand, the hypothalamus and thalamus are immunoreactive for HCN3 and HCN4 subunits, respectively [39], and these subunits are also expressed throughout the cerebellum [71]. Lastly, apical dendrites of hippocampal neurons are immunoreactive for various HCN channels [64-67].

Although the hyperpolarization of the membrane potential activates HCN channels expressed in the central nervous system tissues, a few channels are activated by resting membrane potentials (between -50 and $-60 \mathrm{mV}$ ). The activation of $\mathrm{HCN}$ channels, by resting membrane potentials, brings them closer to the threshold which regulates the action potential [44,72]. Given the importance of HCN channels in excitable cells [44], further studies are needed to understand their regulation as well as the neuropathologies associated with its dysfunction (e.g., epilepsy). 


\section{The Role of HCN Channels in Pain Perception}

Pain affects millions of individuals worldwide [73]. Chronic pain, which is often caused by several and different diseases, affects $\sim 20 \%$ of the adult European population [74], turning it into a co-morbidity factor [75]. There is compelling evidence that pain is strongly related to ion channel regulation and/or modulation associated to neuronal activity in the peripheral nervous system [76]. Hyperpolarization-activated cyclic nucleotide-gated channels have been reported to participate in the pain process [31,77-82], where $I_{h}$ can induce the repetitive firing of primary nociceptive neurons [83-85]. It is not fully clear the specific role of each HCN channel in pain perception. For instance, somatosensory afferent neurons highly express HCN1 and HCN2 subunits [41,77,83], although nociceptors (i.e., small somatosensory neurons) do not express the HCN1 subunit [85]. In contrast, nociceptors highly express the $\mathrm{HCN} 2$ subunit, which drives the firing rate during neuropathic and inflammatory-induced pain $[79,81,82]$. In agreement with HCN2 expression in the nociceptors, the HCN2 knockout mice did not show increased sensitivity to pain (i.e., hyperalgesia) in response to mechanical or thermal stimuli [79]. Additionally, neuropathic and inflammatory-induced pain is not attenuated in HCN1 knockout mice [85].

Diabetic patients develop a painful diabetic neuropathy (PDN) - a chronic pain condition induced by nerve damage [86]. The molecular mechanism of chronic pain in diabetes is poorly understood, and even at present there are no effective treatments [87]. Tsantoulas and colleagues [86] investigated the role of $\mathrm{HCN} 2$ as drivers of diabetic pain using mouse models (for diabetes type 1 and 2). The HCN2 channel activity blockade in small nociceptive neurons suppressed the diabetes-associated allodynia and prevented the nociceptive pathway in the spinal cord in mice [86]. Also, the pharmacological blockade with ivabradine, an $\mathrm{HCN}$ inhibitor, reduced chronic pain in mice with diabetes. These results suggest that selective HCN2 inhibitors might be a valuable treatment strategy for diabetic neuropathies [86]. In addition, Tsantoulas and colleagues [86] found that intracellular cAMP is increased in somatosensory neurons in an animal model of painful diabetes. This increased intracellular cAMP drives the diabetes-associated pain by facilitating the HCN2 activation with the consequent promotion of firing in primary nociceptive nerve fibers [86].

Even though distinct chemotherapeutic drugs have different modes of action, several drugs can also cause chronic pain. Three of this main chemotherapeutic classes, taxanes, platinum-based agents, and vinca alkaloids are commonly associated with chemotherapy-induced peripheral neuropathy (CIPN) [88]. Although antineoplastic drugs have a different mechanism of action and a dose/rate of CIPN occurrence, one common mechanism to these antineoplastic drugs is the change in the ion channel expression for primary afferent sensory neurons [88]. Oxaliplatin can induce peripheral neuropathy with hypersensitivity to mechanical and cold stimuli [88] mediated by changes in $\mathrm{K}^{+}$ channel mRNA in mouse DRGs, with an increase in HCN1 subunit and a down regulation of TREK1, TREK2 (TWIK-Related $\mathrm{K}^{+}$Channel), TRAAK (TWIK-related arachidonic acid-stimulated $\mathrm{K}^{+}$channel), and $\mathrm{K}_{\mathrm{V}} 1.1$ in nociceptors [89,90]. Resta et al. [91] recently showed an HCN current gain of function, a blockade of HCN2 expression, and an upregulation of the HCN regulatory $\beta$-subunit MirP1 in DRG neurons from oxaliplatin-treated rats. Mice treated with the HCN blocker ivabradine, which is a nonselective blocker of all four HCN channels [92], abolished the oxaliplatin-induced hypersensitivity to cold and mechanical hyperalgesia $[82,89]$. Studies in DRG neurons of paclitaxel-treated animals showed changes in the expression of ion channels including the upregulation of $\mathrm{K}_{\mathrm{V}} 1.2, \mathrm{~K}_{\mathrm{V}} 11.3$, $\mathrm{K}_{\mathrm{ir}} 3.1$, and HCN1 channels along with reductions in $\mathrm{K}_{\mathrm{ir}} 1.1, \mathrm{~K}_{\mathrm{ir}} 3.4$, and $\mathrm{K}_{2 \mathrm{P}} 1.1$ channels [93]. These changes in the ion channels' expression are accompanied by the increased excitability of nociceptors [88]. HCN1 channels expression increasingly appears to be a common feature in different antineoplastics, suggesting that HCN1 down regulation may be a therapeutic approach to prevent and/or treat CPIN [88].

Given the importance of HCN channels in the pain process [31,77-80,82,84,94], the reported 3D-structure of the closed (i.e., depolarized) HCN1 subunit has provided new insights on how HCN channels can be modulated for pain treatment, and additionally, address the rational design of new 
highly selective blockers for HCN1 or HCN2 over HCN4 channels, to avoid depressive effects on heart rate.

\section{HCN Channels as a Pharmacological Target for Analgesia}

Nociceptive pain involves the transduction, conduction, transmission, modulation, and perception of noxious signals to the brain [95], which are then converted into an electrical signal [96]. The electrical signal is relayed to the dorsal horn, and then to the brain via spinal projections where the information is assessed, and the appropriate response is generated [96,97]. There are compelling evidence supporting the involvement of HCN1-2 subunits in the transmission of electrical signals and the induction of peripheral pain [77,84,98-101]. Evidence suggests that the inhibition of HCN channels function results in an interruption of electrical signals; therefore, blocking HCN channels can have analgesic effects and reduces pain sensation. For instance, the nonselective HCN channel blocker ZD-7288 (Figure 2) suppresses mechanical and thermal hypersensitivity in different models of neuropathic pain $[77,84,98,99,102]$. Dysfunction of HCN channel activity is associated with the development and maintenance of chronic pain and inhibition of HCN channel activity produces the anti-nociceptive effect $[82,103,104]$. Local or systemic administration of ZD-7288 reduced nociceptive behavior in animals with peripheral nerve injury [98]. At the supraspinal level, increased HCN activity appears to be related to chronic pain and comorbidity. For example, HCN1 expression level was increased in the amygdala of rats with chronic constriction of sciatic nerve (CCI) and inhibition of HCN channels was anti-nociceptive [104]. Increased HCN protein expression level and enhanced $\mathrm{I}_{\mathrm{h}}$ current were also observed in the periaquaductal gray of CCI rats, whereas infusion of ZD-7288 into this brain region attenuated neuropathic pain [52,105]. Moreover, microinfusion of ZD-7288 into the medial prefrontal cortex or the anterior cingulate cortex also produced the anti-nociceptive effect in mice with spared nerve injury [106] or CCI [51]. ZD-7288 infusion into the ventral posterolateral (VPL) nucleus of the thalamus in rats with neuropathic pain or monoarthritis attenuated mechanical allodynia and thermal hyperalgesia in rats with chronic pain [38]. Thus, these results support that the main effect of blockers of HCN channels is on the HCN channels expressed in the peripheral nervous system (PNS). However, there is also evidence that the infusion of HCN blockers in the central nervous system also generates anti-nociceptive effect.

Additionally, further studies where the HCN channel inhibitors ivabradine and gabapentin were used (the latter is a gold standard for neuropathic pain treatment; Figure 2), corroborated the anti-nociceptive effect [82,107]. Gabapentin, which acts by blocking voltage-gated calcium channels, also showed an upregulated activity of the HCN channels [108]. However, the gabapentin binding mechanism and how it modulates HCN channels remains unclear. Recently, Tae et al. [109] showed that gabapentin reduces HCN4 channel-mediated currents through a hyperpolarized shift in the voltage of activation, with minimal changes for HCN1 channels and none for HCN2 channels. Ivabradine, a nonselective $\mathrm{HCN}$ channel blocker with an $\mathrm{IC}_{50}$ of $\sim 4 \mu \mathrm{M}$ for HCN1, HCN2, and HCN4 subunits [110], interacts with the HCN4 subunit pore, binding to amino acid residues Y506, F509, and I510, which stabilize interactions between ivabradine and the HCN4 subunit [111]. On the other hand, ivabradine could interact with the HCN1 subunit pore, binding to amino acid residues Y386, F389, and V390, according to the HCN channel sequence alignment reported by Lee and MacKinnon [4] (Figure 3). A close binding site inspection in the HCN1 structure allows the location of Y386, F389, and V390 residues in the inner cavity, where Y386 and V390 are facing the pore. Further studies are needed to understand the drugs binding to specific amino acid residues, since Y386, F389, and V390 are conserved as members of the voltage-gated pore loop channel superfamily. 
Gabapeptin<smiles>NCC1(CC(=O)O)CCCCC1</smiles>

\section{ZD-7288}<smiles>CCN(c1ccccc1)c1cc(=NC)n(C)c(C)n1</smiles>

\section{Ivabradine}

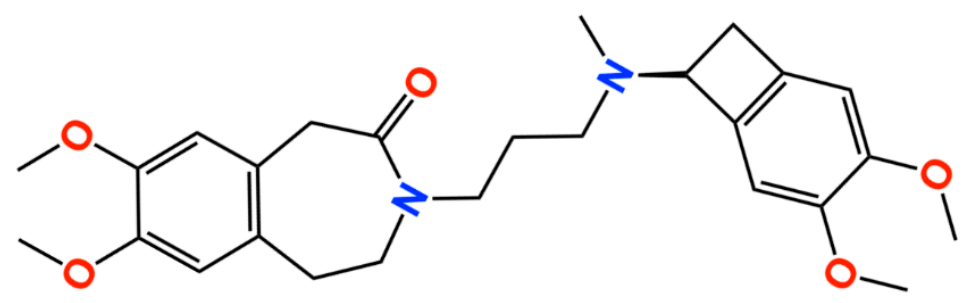

Figure 2. Two-dimensional structures of analgesic drugs targeting HCN channels.

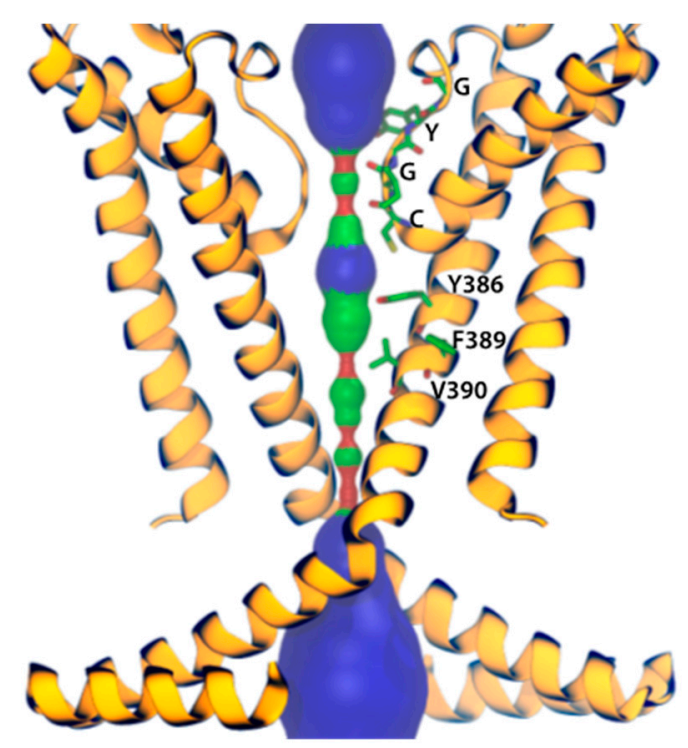

Figure 3. The HCN1 subunit pore. Only two subunits are shown for better visualization. The pore is shown in red where the pore radius is $<0.6 \AA$, green where it is between $0.6 \AA$ and $1.15 \AA$, and blue where it is $>1.15 \AA$. Residues mediating ivabradine binding and those forming the selectivity filter are represented as sticks.

Other inhibitors have a greater affinity for specific HCN channels over others. The structural analogs related to zatebradine EC18 and MEL57A displayed selectivity for homomeric HCN channel isoforms [112,113]. Among the isoform-selective phenylalkylamines, EC18 is 6-fold more selective for the HCN4 subunit than the HCN1 subunit [113], and MEL57A is 170- and 30-fold more selective for the HCN1 subunit than the HCN4 and HCN2 subunits, respectively [112]. Furthermore, several selective 
blockers of the HCN1 channel, 2,2-di-substituted indane derivatives, with 10-fold selectivity for HCN1 over HCN4 have been reported [114]. Among them, the activity of compound 12m, which showed in vitro selectivity $\left(\mathrm{IC}_{50} \mathrm{HCN} 1=6.4 \mu \mathrm{M}, \mathrm{IC}_{50} \mathrm{HCN} 4=5.4 \mu \mathrm{M}\right)$, was tested in a spared nerve injury (SNI) model [114]. The contribution of the HCN1 channel to induced allodynia and a selective HCN1 blocker, compound $\mathbf{1 2 m}$, for treatment of neuropathic pain were displayed [114].

Amino acid residues involved in the binding of drugs to HCN channels may also be different. Unlike ivabradine, which is predicted to bind to amino acid residues Y386, F389, and V390 of the HCN1 subunit, ZD-7288 binds to residues A425 and I432 located in the S6 transmembrane domain of the HCN2 subunit [115]. Nevertheless, the HCN1 3D-structure (PDB ID: 5U6O) had an enormous impact in understanding structure-function relationships for these channels. Despite the fact it has not bound ligand(s), it could improve our comprehension regarding potential drugs binding sites at the HCN channels pore because the structure might help to localize in a 3D framework the residue(s) which, when mutated, alter the binding of HCN blockers. However, to unravel the complex mechanisms of actions of blockers, the combination of different multidisciplinary strategies is required, as well as the obtaining of new HCN structures in different conformational states with and without ligands. This structural knowledge could lead to improving future computational studies using methods such as docking and molecular dynamics simulations, because so far most of theoretical studies that have been done regarding HCN-drug binding mechanisms were done using models of those channels $[111,116,117]$. Improved computational studies will give structural insights to development of new HCN modulators (activators and inhibitors), which may be useful for the treatment of several pathologies such as arrhythmias, Parkinson's disease, and epilepsy [44,118-123]. Over the last years, the synergy between both experimental and theoretical approaches to study protein-drug interactions have proved to be successful when used to design new drugs targeting ion channels, as well as to study their binding mechanisms at an atomistic and molecular level [124-126].

Regarding anesthetic drugs, there is compelling evidence supporting the involvement of ion channels and receptors, such as type A gamma-aminobutyric acid, N-methyl-D-aspartic acid, glycine receptors, and $\mathrm{K}_{2 \mathrm{P}}$ and $\mathrm{HCN}$ channels $[110,127,128]$. Anesthetic drugs induce neuronal hyperpolarization of the membrane potential, thus decreasing the excitability in the central nervous system and causing consciousness status. This hyperpolarization is generated mainly by the activation of $\mathrm{K}_{2 \mathrm{P}}$ channels as well as gamma-aminobutyric acid (GABA), NMDA and glycine receptors. On the other hand, a wide range of volatile anesthetics (e.g., enflurane, isoflurane, halothane [129-133], and xenon [134]), intravenous (e.g., pentobarbital [135], ketamine $[136,137]$, and propofol $[45,47,138])$ agents, and adjuncts including loperamide ( $\mu$-opiate receptor agonist) $[139,140]$ and $\alpha 2$-receptor agonists (e.g., clonidine and dexmedetomidine [141-143]) inhibit HCN channel activity [144], and thereby prevent membrane depolarization. The general anesthetic propofol (2,6-di-isopropylphenol) (Figure 4) selectively inhibits HCN1 channels versus HCN2, 3, and 4 [45,138]. Consequently, Tibbs et al. [103] hypothesized that propofol, and congeners, should be antihyperalgesic. Analogs of propofol (alkyl-substituted) present different levels of potency regarding $\mathrm{HCN} 1$ inhibition, $\mathrm{GABA}_{\mathrm{A}}$ receptor $\left(\mathrm{GABA}_{\mathrm{A}}-\mathrm{R}\right)$ potentiation, and general anesthesia. Thus, 2,6- and 2,4-di-tert-butylphenol (2,6- and 2,4-DTBP, respectively) were shown to be more potent HCN1 antagonists than propofol while 2,6- and 2,4-di-sec-butylphenol (2,6- and 2,4-DSBP, respectively) were less potent [103]. In contrast, DSBPs (di-sec-butylphenols), but not DTBPs (di-tert-butylphenols), enhance $\mathrm{GABA}_{\mathrm{A}}$ receptor activity and are general anesthetics. Also, in a neuropathic pain model, 2,6-DTBP and subhypnotic propofol were antihyperalgesic [103]. These findings are consistent with the fact that alkylphenols are acting through a pathway non-associated with the $\mathrm{GABA}_{\mathrm{A}}$ receptor, and suggest that central HCN1 channel antagonism may be of limited importance to general anesthesia [103]. Alkylphenols act directly on HCN channels, and have a small effect modifying the lipid bilayer at therapeutic concentrations, despite its hydrophobic characteristic [103]. Thus, the alkylphenol antihyperalgesic target may be the HCN1 channels in the damaged PNS [103]. 


\section{Propofol}<smiles>CC(C)c1cccc(C(C)C)c1O</smiles>

Ketamine

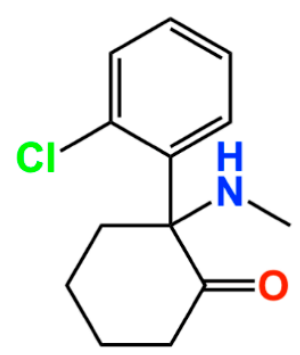

Lidocaine<smiles>CCN(CC)CC(=O)Nc1c(C)cccc1C</smiles>

Figure 4. Two-dimensional structures of anesthetic drugs targeting HCN channels.

The volatile anesthetics (i.e., enflurane, halothane, and isoflurane) have previously been shown to inhibit the $\mathrm{I}_{\mathrm{h}}$ current as well as the current generated by HCN1 and HCN2 channels heterologously expressed [129-133]. Zhou et al. [145] tested the immobilizing, hypnotic, and amnestic effects of isoflurane and sevoflurane in $\mathrm{HCN} 1^{-/}$mice and $\mathrm{HCN} 1^{\mathrm{f} / \mathrm{f}, \mathrm{cre}}$ mice (with a $\mathrm{HCN} 1$ deletion restricted to the forebrain). These tests confirm a role for volatile anesthetic-mediated inhibition of HCN1 when contributing to hypnosis, and likely amnesia but not immobility [144].

For instance, the intravenous anesthetic drug propofol (Figure 4) inhibits $\mathrm{I}_{\mathrm{h}}$ in hippocampal pyramidal neurons and cortical pyramidal neurons [45] by blocking the HCN1 [138] subunit. Using a heterologous model of recombinant $\mathrm{HCN} 2$ and HCN4 subunit proteins, Cacheaux et al. reported that propofol can also block both subunits at clinically relevant concentrations $(<10 \mu \mathrm{M})$. These findings are supported by results from HCN1 knockout mice, which were less sensitive to the propofol effects [133].

Ketamine, a drug with anesthetic, analgesic, and psychotropic effects, also inhibits the HCN1 subunit in cortical pyramidal neurons (Figure 4), and its effects are attenuated in HCN1 knockout mice $[136,146]$. On the other hand, the local anesthetic lidocaine (Figure 4) inhibits HCN1, HCN2, and $\mathrm{HCN} 4$ subunits, as well as heteromeric $\mathrm{HCN} 1-\mathrm{HCN} 2$ channels acting in a dose-dependent manner over a concentration range relevant for systemic use [147]. However, propofol, ketamine, and lidocaine action mechanisms are not completely understood due to the lack of information about the amino acids that integrate their binding site. The HCN1 three-dimensional structure provides new insights regarding how $\mathrm{HCN}$ channels can be inhibited to treat pain, as well as information regarding their biophysical properties [124,125].

Volatile anesthetic drugs, such as the commonly used isoflurane and halothane, decrease $\mathrm{I}_{\mathrm{h}}$ in cortical neurons mediated by monomeric and heteromeric HCN2 and HCN1 channels [132,133]. Isoflurane effects have been studied in the HCN1 subunit. The HCN1 knockout revealed that isoflurane targets the $\mathrm{HCN} 1$ subunit by reducing $\mathrm{I}_{\mathrm{h}}$ in motoneurons and cortical pyramidal neurons [133]. In these neurons, from HCN1 knockout mice, electrical changes induced by the isoflurane anesthetic were absent, verifying the HCN1 subunit specific contribution to isoflurane effects [133].

\section{Challenges and Future Directions in Structure-Based Drug Design Targeting HCN Channels}

Rational drug design targeting ion channels with specific properties is a constantly evolving research field. The design offers revolutionary advantages for the development of new therapeutic drugs through the use of newly developed methods such as computational tools and structure-based approaches, where the structural, physical-chemical, and pharmacological properties of the ligands and targets are critical to gain high potency and binding affinity.

Nowadays, for drugs whose molecular target is an ion channel with a known 3D structure, experimental and theoretical approaches are used to study protein-ligand interactions. Structure-based 
drug design (SBDD) is most powerful when it is a part of an entire drug discovery process. This is a handy and versatile computational tool that examine the 3D structure of a given target (previously obtained by X-ray crystallography, nuclear magnetic resonance (NMR) spectroscopy, cryoelectron microscopy, or any other molecular modeling technique [148]), followed by the study of binding properties and affinity of a given set of ligands for their molecular target [125]. This approach, coupled with combinatorial chemistry may lead to the parallel synthesis of focused compound libraries, and has been particularly helpful for the identification of hits and lead compounds, targeting membrane proteins in cases where traditional methods have failed due to the target's nature [149]. It is also important to be aware that the SBDD guides the discovery of a drug lead, which is not a drug product, but, especially, a molecule with affinity for a target in at least the micromolar range [150]. Additionally, the crosstalk between different research areas such as medical chemistry, biochemistry, bioinformatics, genomics, proteomics, and metabolomics has contributed to the development of new computational tools for the rational design of ion channel modulators [125]. Thus, the use of established methods (i.e., docking, virtual screening, de novo drug design, and molecular simulations involving electrophysiological approximations [151]) will radically change the way in which new modulators targeting ion channels with higher potency and affinity are designed. In this way, the reported three-dimensional structure of the HCN1 subunit will provide new insights on how HCN channels can be modulated for pain treatment.

\section{Conclusions}

The cDNA cloning and partial characterization of different HCN subunits have set the pace for their extensive study using biochemical, biophysical, genetic, and cellular approaches. HCN subunits are highly regulated proteins which respond to different stimuli.

Hyperpolarization-activated cyclic nucleotide-gated channels are widely distributed in both excitable (and non-excitable) cells of the nervous system and the heart. Their expression patterns in different tissue and cells are affected by different pathological conditions. These channels transmit electrical signals in excitable cells such as neurons; for instance, they control heart rate and also inhibit pain [97,110]. Despite the involvement of HCN channels in various diseases [44], it is unclear how they can be pharmacologically targeted to alleviate illness symptoms such as pain. Hyperpolarization-activated cyclic nucleotide-gated channels are overexpressed in inflammatory and neuropathic pain, and HCN blockers have been shown to reduce neuronal excitability and to ameliorate painful states in animal models. However, HCN channels are critical in cardiac action potential, and HCN blockers used so far in pre-clinical models (e.g., ZD-7288 and ivabradine) do not discriminate between cardiac and non-cardiac $\mathrm{HCN}$ isoforms, generating bradycardia by the inhibition of HCN4-dependent pacemaking activity in the heart [82,107].

Therefore, the 3D structure of the human HCN1 subunit [4] has opened new possibilities for the rational design of highly-selective HCN modulators, especially those handy to treat pain. Based on the HCN1 structure, it is interesting to speculate about the structure and functional relationship associated with HCN blockers. Further functional studies coupled with mutagenesis experiments as well as computational studies are needed to identify the key amino acids that integrate drug binding sites in HCN channels.

Author Contributions: L.Z. conceived the review, D.R., R.Z., G.C., and L.Z. conducted the literature review and wrote the manuscript.

Funding: This research received no external funding.

Acknowledgments: We thank all research staff at the Medical Research Center (CIM) and to the Associative Research Program on Gastric Cancer (PIA-CG) of Universidad de Talca for their technical support and for the helpful comments and stimulating discussions. We thank Marcelo A. Catalán for critical reading of the manuscript, helpful comments, and stimulating discussions. The authors would also like to express their sincere gratitude to M.A. Claudia Daza Botero for assistance with manuscript editing.

Conflicts of Interest: The authors declare no conflict of interest. 


\section{References}

1. Gauss, R.; Seifert, R.; Kaupp, U.B. Molecular identification of a hyperpolarization-activated channel in sea urchin sperm. Nature 1998, 393, 583-587. [CrossRef] [PubMed]

2. Ludwig, A.; Zong, X.; Jeglitsch, M.; Hofmann, F.; Biel, M. A family of hyperpolarization-activated mammalian cation channels. Nature 1998, 393, 587-591. [CrossRef] [PubMed]

3. Santoro, B.; Liu, D.T.; Yao, H.; Bartsch, D.; Kandel, E.R.; Siegelbaum, S.A.; Tibbs, G.R. Identification of a gene encoding a hyperpolarization-activated pacemaker channel of brain. Cell 1998, 93, 717-729. [CrossRef]

4. Lee, C.-H.; MacKinnon, R. Structures of the human HCN1 hyperpolarization-activated channel. Cell 2017, 168, 111-120. [CrossRef] [PubMed]

5. DiFrancesco, D.; Tortora, P. Direct activation of cardiac pacemaker channels by intracellular cyclic amp. Nature 1991, 351, 145-147. [CrossRef] [PubMed]

6. Wang, J.; Chen, S.; Nolan, M.F.; Siegelbaum, S.A. Activity-dependent regulation of HCN pacemaker channels by cyclic amp. Neuron 2002, 36, 451-461. [CrossRef]

7. Biel, M.; Wahl-Schott, C.; Michalakis, S.; Zong, X. Hyperpolarization-activated cation channels: From genes to function. Physiol. Rev. 2009, 89, 847-885. [CrossRef] [PubMed]

8. Sunkara, M.R.; Schwabe, T.; Ehrlich, G.; Kusch, J.; Benndorf, K. All four subunits of HCN2 channels contribute to the activation gating in an additive but intricate manner. J. Gen. Physiol. 2018. [CrossRef] [PubMed]

9. Stieber, J.; Thomer, A.; Much, B.; Schneider, A.; Biel, M.; Hofmann, F. Molecular basis for the different activation kinetics of the pacemaker channels HCN2 and HCN4. J. Biol. Chem. 2003, 278, 33672-33680. [CrossRef] [PubMed]

10. Wainger, B.J.; DeGennaro, M.; Santoro, B.; Siegelbaum, S.A.; Tibbs, G.R. Molecular mechanism of cAMP modulation of HCN pacemaker channels. Nature 2001, 411, 805-810. [CrossRef] [PubMed]

11. Stieber, J.; Stöckl, G.; Herrmann, S.; Hassfurth, B.; Hofmann, F. Functional expression of the human HCN3 channel. J. Biol. Chem. 2005, 280, 34635-34643. [CrossRef] [PubMed]

12. Ying, S.-W.; Tibbs, G.R.; Picollo, A.; Abbas, S.Y.; Sanford, R.L.; Accardi, A.; Hofmann, F.; Ludwig, A.; Goldstein, P.A. Pip 2 -mediated HCN3 channel gating is crucial for rhythmic burst firing in thalamic intergeniculate leaflet neurons. J. Neurosci. 2011, 31, 10412-10423. [CrossRef] [PubMed]

13. Wilson, G.W.; Garthwaite, J. Hyperpolarization-activated ion channels as targets for nitric oxide signalling in deep cerebellar nuclei. Eur. J. Neurosci. 2010, 31, 1935-1945. [CrossRef] [PubMed]

14. Kusch, J.; Biskup, C.; Thon, S.; Schulz, E.; Nache, V.; Zimmer, T.; Schwede, F.; Benndorf, K. Interdependence of receptor activation and ligand binding in HCN2 pacemaker channels. Neuron 2010, 67, 75-85. [CrossRef] [PubMed]

15. Kusch, J.; Thon, S.; Schulz, E.; Biskup, C.; Nache, V.; Zimmer, T.; Seifert, R.; Schwede, F.; Benndorf, K. How subunits cooperate in cAMP-induced activation of homotetrameric HCN2 channels. Nat. Chem. Biol. 2011, 8, 162-169. [CrossRef] [PubMed]

16. Frère, S.G.; Kuisle, M.; Lüthi, A. Regulation of recombinant and native hyperpolarization-activated cation channels. Mol. Neurobiol. 2004, 30, 279-305. [CrossRef]

17. Much, B.; Wahl-Schott, C.; Zong, X.; Schneider, A.; Baumann, L.; Moosmang, S.; Ludwig, A.; Biel, M. Role of subunit heteromerization and $n$-linked glycosylation in the formation of functional hyperpolarization-activated cyclic nucleotide-gated channels. J. Biol. Chem. 2003, 278, 43781-43786. [CrossRef] [PubMed]

18. Bezanilla, F. The voltage sensor in voltage-dependent ion channels. Physiol. Rev. 2000, 80, 555-592. [CrossRef] [PubMed]

19. Chen, J.; Mitcheson, J.S.; Lin, M.; Sanguinetti, M.C. Functional roles of charged residues in the putative voltage sensor of the HCN2 pacemaker channel. J. Biol. Chem. 2000, 275, 36465-36471. [CrossRef] [PubMed]

20. Jiang, Y.; Ruta, V.; Chen, J.; Lee, A.; MacKinnon, R. The principle of gating charge movement in a voltage-dependent $\mathrm{k}^{+}$channel. Nature 2003, 423, 42-48. [CrossRef] [PubMed]

21. Vaca, L.; Stieber, J.; Zong, X.; Ludwig, A.; Hofmann, F.; Biel, M. Mutations in the s4 domain of a pacemaker channel alter its voltage dependence. FEBS Lett. 2000, 479, 35-40. [CrossRef]

22. Zhou, Y.; Morais-Cabral, J.H.; Kaufman, A.; MacKinnon, R. Chemistry of ion coordination and hydration revealed by a $\mathrm{k}^{+}$channel-fab complex at 2.0 a resolution. Nature 2001, 414, 43-48. [CrossRef] [PubMed] 
23. Yu, X.; Duan, K.-L.; Shang, C.-F.; Yu, H.-G.; Zhou, Z. Calcium influx through hyperpolarization-activated cation channels ( $\mathrm{I}_{\mathrm{h}}$ channels) contributes to activity-evoked neuronal secretion. Proc. Natl. Acad. Sci. USA 2004, 101, 1051-1056. [CrossRef] [PubMed]

24. Yu, X.; Chen, X.-W.; Zhou, P.; Yao, L.; Liu, T.; Zhang, B.; Li, Y.; Zheng, H.; Zheng, L.-H.; Zhang, C.X.; et al. Calcium influx through if channels in rat ventricular myocytes. Am. J. Physiol. Cell Physiol. 2007, 292, C1147-C1155. [CrossRef] [PubMed]

25. Zhou, Z.; Neher, E. Calcium permeability of nicotinic acetylcholine receptor channels in bovine adrenal chromaffin cells. Pflugers Arch. Eur. J. Physiol. 1993, 425, 511-517. [CrossRef]

26. Schneggenburger, R.; Zhou, Z.; Konnerth, A.; Neher, E. Fractional contribution of calcium to the cation current through glutamate receptor channels. Neuron 1993, 11, 133-143. [CrossRef]

27. Burnashev, N.; Zhou, Z.; Neher, E.; Sakmann, B. Fractional calcium currents through recombinant glur channels of the nmda, ampa and kainate receptor subtypes. J. Physiol. 1995, 485, 403-418. [CrossRef] [PubMed]

28. Dzeja, C.; Hagen, V.; Kaupp, U.B.; Frings, S. $\mathrm{Ca}^{2+}$ permeation in cyclic nucleotide-gated channels. EMBO J. 1999, 18, 131-144. [CrossRef] [PubMed]

29. Zhou, Z.; Bers, D.M. Ca ${ }^{2+}$ influx via the L-type $\mathrm{ca}^{2+}$ channel during tail current and above current reversal potential in ferret ventricular myocytes. J. Physiol. 2000, 523, 57-66. [CrossRef] [PubMed]

30. Craven, K.B.; Zagotta, W.N. Cng and HCN channels: Two peas, one pod. Annu. Rev. Physiol. 2006, 68, 375-401. [CrossRef] [PubMed]

31. Wahl-Schott, C.; Biel, M. HCN channels: Structure, cellular regulation and physiological function. Cell. Mol. Life Sci. 2009, 66, 470-494. [CrossRef] [PubMed]

32. Zagotta, W.N.; Olivier, N.B.; Black, K.D.; Young, E.C.; Olson, R.; Gouaux, E. Structural basis for modulation and agonist specificity of HCN pacemaker channels. Nature 2003, 425, 200-205. [CrossRef] [PubMed]

33. Craven, K.B.; Olivier, N.B.; Zagotta, W.N. C-terminal movement during gating in cyclic nucleotide-modulated channels. J. Biol. Chem. 2008, 283, 14728-14738. [CrossRef] [PubMed]

34. Lolicato, M.; Nardini, M.; Gazzarrini, S.; Möller, S.; Bertinetti, D.; Herberg, F.W.; Bolognesi, M.; Martin, H.; Fasolini, M.; Bertrand, J.A.; et al. Tetramerization dynamics of C-terminal domain underlies isoform-specific cAMP gating in hyperpolarization-activated cyclic nucleotide-gated channels. J. Biol. Chem. 2011, 286, 44811-44820. [CrossRef] [PubMed]

35. Lolicato, M.; Bucchi, A.; Arrigoni, C.; Zucca, S.; Nardini, M.; Schroeder, I.; Simmons, K.; Aquila, M.; DiFrancesco, D.; Bolognesi, M.; et al. Cyclic dinucleotides bind the C-linker of HCN4 to control channel cAMP responsiveness. Nat. Chem. Biol. 2014, 10, 457-462. [CrossRef] [PubMed]

36. Moller, S.; Alfieri, A.; Bertinetti, D.; Aquila, M.; Schwede, F.; Lolicato, M.; Rehmann, H.; Moroni, A.; Herberg, F.W. Cyclic nucleotide mapping of hyperpolarization-activated cyclic nucleotide-gated (HCN) channels. ACS Chem. Biol. 2014, 9, 1128-1137. [CrossRef] [PubMed]

37. Taraska, J.W.; Puljung, M.C.; Olivier, N.B.; Flynn, G.E.; Zagotta, W.N. Mapping the structure and conformational movements of proteins with transition metal ion fret. Nat. Methods 2009, 6, 532-537. [CrossRef] [PubMed]

38. Ding, W.; You, Z.; Shen, S.; Chen, L.; Zhu, S.; Mao, J. Inhibition of HCN channel activity in the thalamus attenuates chronic pain in rats. Neurosci. Lett. 2016, 631, 97-103. [CrossRef] [PubMed]

39. Notomi, T.; Shigemoto, R. Immunohistochemical localization of $\mathrm{I}_{\mathrm{h}}$ channel subunits, $\mathrm{HCN1}-4$, in the rat brain. J. Comp. Neurol. 2004, 471, 241-276. [CrossRef] [PubMed]

40. Moosmang, S.; Biel, M.; Hofmann, F.; Ludwig, A. Differential distribution of four hyperpolarization-activated cation channels in mouse brain. Biol. Chem. 1999, 380, 975-980. [CrossRef] [PubMed]

41. Moosmang, S.; Stieber, J.; Zong, X.; Biel, M.; Hofmann, F.; Ludwig, A. Cellular expression and functional characterization of four hyperpolarization-activated pacemaker channels in cardiac and neuronal tissues. Eur. J. Biochem. 2001, 268, 1646-1652. [CrossRef] [PubMed]

42. Santoro, B.; Chen, S.; Lüthi, A.; Pavlidis, P.; Shumyatsky, G.P.; Tibbs, G.R.; Siegelbaum, S.A. Molecular and functional heterogeneity of hyperpolarization-activated pacemaker channels in the mouse cns. J. Neurosci. 2000, 20, 5264-5275. [CrossRef] [PubMed]

43. Ludwig, A.; Zong, X.; Stieber, J.; Hullin, R.; Hofmann, F.; Biel, M. Two pacemaker channels from human heart with profoundly different activation kinetics. EMBO J. 1999, 18, 2323-2329. [CrossRef] [PubMed]

44. He, C.; Chen, F.; Li, B.; Hu, Z. Neurophysiology of HCN channels: From cellular functions to multiple regulations. Prog. Neurobiol. 2014, 112, 1-23. [CrossRef] [PubMed] 
45. Chen, $X . ;$ Shu, S.; Bayliss, D.A. Suppression of $\mathrm{I}_{\mathrm{h}}$ contributes to propofol-induced inhibition of mouse cortical pyramidal neurons. J. Neurophysiol. 2005, 94, 3872-3883. [CrossRef] [PubMed]

46. Nolan, M.F.; Malleret, G.; Lee, K.H.; Gibbs, E.; Dudman, J.T.; Santoro, B.; Yin, D.; Thompson, R.F.; Siegelbaum, S.A.; Kandel, E.R.; et al. The hyperpolarization-activated HCN1 channel is important for motor learning and neuronal integration by cerebellar purkinje cells. Cell 2003, 115, 551-564. [CrossRef]

47. Ying, S.-W.; Abbas, S.Y.; Harrison, N.L.; Goldstein, P.A. Propofol block of $\mathrm{I}_{\mathrm{h}}$ contributes to the suppression of neuronal excitability and rhythmic burst firing in thalamocortical neurons. Eur. J. Neurosci. 2006, 23, 465-480. [CrossRef] [PubMed]

48. Kim, C.S.; Chang, P.Y.; Johnston, D. Enhancement of dorsal hippocampal activity by knockdown of HCN1 channels leads to anxiolytic- and antidepressant-like behaviors. Neuron 2012, 75, 503-516. [CrossRef] [PubMed]

49. Okamoto, T.; Harnett, M.T.; Morikawa, H. Hyperpolarization-activated cation current $\left(\mathrm{I}_{\mathrm{h}}\right)$ is an ethanol target in midbrain dopamine neurons of mice. J. Neurophysiol. 2006, 95, 619-626. [CrossRef] [PubMed]

50. Shin, M.; Simkin, D.; Suyeoka, G.M.; Chetkovich, D.M. Evaluation of HCN2 abnormalities as a cause of juvenile audiogenic seizures in black swiss mice. Brain Res. 2006, 1083, 14-20. [CrossRef] [PubMed]

51. Koga, K.; Descalzi, G.; Chen, T.; Ko, H.-G.; Lu, J.; Li, S.; Son, J.; Kim, T.; Kwak, C.; Huganir, R.L.; et al. Coexistence of two forms of ltp in acc provides a synaptic mechanism for the interactions between anxiety and chronic pain. Neuron 2015, 85, 377-389. [CrossRef] [PubMed]

52. Du, L.; Wang, S.-J.; Cui, J.; He, W.-J.; Ruan, H.-Z. The role of HCN channels within the periaqueductal gray in neuropathic pain. Brain Res. 2013, 1500, 36-44. [CrossRef] [PubMed]

53. Herrmann, S.; Schnorr, S.; Ludwig, A. HCN channels-Modulators of cardiac and neuronal excitability. Int. J. Mol. Sci. 2015, 16, 1429-1447. [CrossRef] [PubMed]

54. Munsch, T.; Pape, H.C. Modulation of the hyperpolarization-activated cation current of rat thalamic relay neurones by intracellular pH. J. Physiol. 1999, 519, 493-504. [CrossRef] [PubMed]

55. Pian, P.; Bucchi, A.; Robinson, R.B.; Siegelbaum, S.A. Regulation of gating and rundown of HCN hyperpolarization-activated channels by exogenous and endogenous Pip 2 . J. Gen. Physiol. 2006, 128, 593-604. [CrossRef] [PubMed]

56. Zolles, G.; Klöcker, N.; Wenzel, D.; Weisser-Thomas, J.; Fleischmann, B.K.; Roeper, J.; Fakler, B. Pacemaking by HCN channels requires interaction with phosphoinositides. Neuron 2006, 52, 1027-1036. [CrossRef] [PubMed]

57. Zong, X.; Stieber, J.; Ludwig, A.; Hofmann, F.; Biel, M. A single histidine residue determines the pH sensitivity of the pacemaker channel HCN2. J. Biol. Chem. 2001, 276, 6313-6319. [CrossRef] [PubMed]

58. Arinsburg, S.S.; Cohen, I.S.; Yu, H.-G. Constitutively active src tyrosine kinase changes gating of HCN4 channels through direct binding to the channel proteins. J. Cardiovasc. Pharmacol. 2006, 47, 578-586. [CrossRef] [PubMed]

59. Li, C.-H.; Zhang, Q.; Teng, B.; Mustafa, S.J.; Huang, J.-Y.; Yu, H.-G. Src tyrosine kinase alters gating of hyperpolarization-activated HCN4 pacemaker channel through $\mathrm{Tyr}^{531}$. Am. J. Physiol. Cell Physiol. 2008, 294, C355-C362. [CrossRef] [PubMed]

60. Fogle, K.J.; Lyashchenko, A.K.; Turbendian, H.K.; Tibbs, G.R. HCN pacemaker channel activation is controlled by acidic lipids downstream of diacylglycerol kinase and phospholipase A2. J. Neurosci. 2007, 27, 2802-2814. [CrossRef] [PubMed]

61. Liu, Z.; Bunney, E.B.; Appel, S.B.; Brodie, M.S. Serotonin reduces the hyperpolarization-activated current $\left(\mathrm{I}_{\mathrm{h}}\right)$ in ventral tegmental area dopamine neurons: Involvement of 5- CA1 receptors and protein kinase C. J. Neurophysiol. 2003, 90, 3201-3212. [CrossRef] [PubMed]

62. Reetz, O.; Strauss, U. Protein kinase c activation inhibits rat and human hyperpolarization activated cyclic nucleotide gated channel (HCN)1-Mediated current in mammalian cells. Cell. Physiol. Biochem. 2013, 31, 532-541. [CrossRef] [PubMed]

63. Fürst, O.; D'Avanzo, N. Isoform dependent regulation of human HCN channels by cholesterol. Sci. Rep. 2015, 5. [CrossRef] [PubMed]

64. Magee, J.C.; Carruth, M. Dendritic voltage-gated ion channels regulate the action potential firing mode of hippocampal CA1 pyramidal neurons. J. Neurophysiol. 1999, 82, 1895-1901. [CrossRef] [PubMed]

65. Magee, J.C. Dendritic $\mathrm{I}_{\mathrm{h}}$ normalizes temporal summation in hippocampal CA1 neurons. Nat. Neurosci. 1999, 2, 508-514. [CrossRef] [PubMed]

66. Magee, J.C. Dendritic integration of excitatory synaptic input. Nat. Rev. Neurosci. 2000, 1, 181-190. [CrossRef] [PubMed] 
67. Magee, J.C. Dendritic mechanisms of phase precession in hippocampal CA1 pyramidal neurons. J. Neurophysiol. 2001, 86, 528-532. [CrossRef] [PubMed]

68. Shi, W.; Wymore, R.; Yu, H.; Wu, J.; Wymore, R.T.; Pan, Z.; Robinson, R.B.; Dixon, J.E.; McKinnon, D.; Cohen, I.S. Distribution and prevalence of hyperpolarization-activated cation channel (HCN) mrna expression in cardiac tissues. Circ. Res. 1999, 85, e1-e6. [CrossRef] [PubMed]

69. Stieber, J.; Hofmann, F.; Ludwig, A. Pacemaker channels and sinus node arrhythmia. Trends Cardiovasc. Med. 2004, 14, 23-28. [CrossRef] [PubMed]

70. Lujan, R.; Albasanz, J.L.; Shigemoto, R.; Juiz, J.M. Preferential localization of the hyperpolarization-activated cyclic nucleotide-gated cation channel subunit HCN1 in basket cell terminals of the rat cerebellum. Eur. J. Neurosci. 2005, 21, 2073-2082. [CrossRef] [PubMed]

71. Zuniga, R.; Gonzalez, D.; Valenzuela, C.; Brown, N.; Zuniga, L. Expression and cellular localization of HCN channels in rat cerebellar granule neurons. Biochem. Biophys. Res. Commun. 2016, 478, 1429-1435. [CrossRef] [PubMed]

72. Benarroch, E.E. HCN channels: Function and clinical implications. Neurology 2013, 80, 304-310. [CrossRef] [PubMed]

73. Bouhassira, D.; Lantéri-Minet, M.; Attal, N.; Laurent, B.; Touboul, C. Prevalence of chronic pain with neuropathic characteristics in the general population. Pain 2008, 136, 380-387. [CrossRef] [PubMed]

74. Breivik, H.; Collett, B.; Ventafridda, V.; Cohen, R.; Gallacher, D. Survey of chronic pain in europe: Prevalence, impact on daily life, and treatment. Eur. J. Pain 2006, 10, 287-333. [CrossRef] [PubMed]

75. Van Hecke, O.; Torrance, N.; Smith, B.H. Chronic pain epidemiology and its clinical relevance. Br. J. Anaesth. 2013, 111, 13-18. [CrossRef] [PubMed]

76. Tibbs, G.R.; Posson, D.J.; Goldstein, P.A. Voltage-gated ion channels in the pns: Novel therapies for neuropathic pain? Trends Pharmacol. Sci. 2016, 37, 522-542. [CrossRef] [PubMed]

77. Chaplan, S.R.; Guo, H.-Q.; Lee, D.H.; Luo, L.; Liu, C.; Kuei, C.; Velumian, A.A.; Butler, M.P.; Brown, S.M.; Dubin, A.E. Neuronal hyperpolarization-activated pacemaker channels drive neuropathic pain. J. Neurosci. 2003, 23, 1169-1178. [CrossRef] [PubMed]

78. Baruscotti, M.; Bottelli, G.; Milanesi, R.; DiFrancesco, J.C.; DiFrancesco, D. HCN-related channelopathies. Pflugers Arch. Eur. J. Physiol. 2010, 460, 405-415. [CrossRef] [PubMed]

79. Emery, E.C.; Young, G.-T.; Berrocoso, E.M.; Chen, L.; McNaughton, P.A. HCN2 ion channels play a central role in inflammatory and neuropathic pain. Science 2011, 333, 1462-1466. [CrossRef] [PubMed]

80. Weng, X.; Smith, T.; Sathish, J.; Djouhri, L. Chronic inflammatory pain is associated with increased excitability and hyperpolarization-activated current $\left(\mathrm{I}_{\mathrm{h}}\right)$ in $\mathrm{C}$ - but not a $\delta$-nociceptors. Pain 2012, 153, 900-914. [CrossRef] [PubMed]

81. Emery, E.C.; Young, G.T.; McNaughton, P.A. HCN2 ion channels: An emerging role as the pacemakers of pain. Trends Pharmacol. Sci. 2012, 33, 456-463. [CrossRef] [PubMed]

82. Young, G.T.; Emery, E.C.; Mooney, E.R.; Tsantoulas, C.; McNaughton, P.A. Inflammatory and neuropathic pain are rapidly suppressed by peripheral block of hyperpolarisation-activated cyclic nucleotide-gated ion channels. Pain 2014, 155, 1708-1719. [CrossRef] [PubMed]

83. Tu, H.; Deng, L.; Sun, Q.; Yao, L.; Han, J.-S.; Wan, Y. Hyperpolarization-activated, cyclic nucleotide-gated cation channels: Roles in the differential electrophysiological properties of rat primary afferent neurons. J. Neurosci. Res. 2004, 76, 713-722. [CrossRef] [PubMed]

84. Luo, L.; Chang, L.; Brown, S.M.; Ao, H.; Lee, D.H.; Higuera, E.S.; Dubin, A.E.; Chaplan, S.R. Role of peripheral hyperpolarization-activated cyclic nucleotide-modulated channel pacemaker channels in acute and chronic pain models in the rat. Neuroscience 2007, 144, 1477-1485. [CrossRef] [PubMed]

85. Momin, A.; Cadiou, H.; Mason, A.; McNaughton, P.A. Role of the hyperpolarization-activated current $\mathrm{I}_{\mathrm{h}}$ in somatosensory neurons. J. Physiol. 2008, 586, 5911-5929. [CrossRef] [PubMed]

86. Tsantoulas, C.; Laínez, S.; Wong, S.; Mehta, I.; Vilar, B.; McNaughton, P.A. Hyperpolarization-activated cyclic nucleotide-gated 2 (HCN2) ion channels drive pain in mouse models of diabetic neuropathy. Sci. Transl. Med. 2017, 9. [CrossRef] [PubMed]

87. Schreiber, A.K.; Nones, C.F.; Reis, R.C.; Chichorro, J.G.; Cunha, J.M. Diabetic neuropathic pain: Physiopathology and treatment. World J. Diabetes 2015, 6, 432-444. [CrossRef] [PubMed]

88. Aromolaran, K.A.; Goldstein, P.A. Ion channels and neuronal hyperexcitability in chemotherapy-induced peripheral neuropathy: Cause and effect? Mol. Pain 2017, 13, 1-24. [CrossRef] [PubMed] 
89. Descoeur, J.; Pereira, V.; Pizzoccaro, A.; Francois, A.; Ling, B.; Maffre, V.; Couette, B.; Busserolles, J.; Courteix, C.; Noel, J.; et al. Oxaliplatin-induced cold hypersensitivity is due to remodelling of ion channel expression in nociceptors. EMBO Mol. Med. 2011, 3, 266-278. [CrossRef] [PubMed]

90. Pereira, V.; Busserolles, J.; Christin, M.; Devilliers, M.; Poupon, L.; Legha, W.; Alloui, A.; Aissouni, Y.; Bourinet, E.; Lesage, F.; et al. Role of the trek2 potassium channel in cold and warm thermosensation and in pain perception. Pain 2014, 155, 2534-2544. [CrossRef] [PubMed]

91. Resta, F.; Micheli, L.; Laurino, A.; Spinelli, V.; Mello, T.; Sartiani, L.; Di Cesare Mannelli, L.; Cerbai, E.; Ghelardini, C.; Romanelli, M.N.; et al. Selective HCN1 block as a strategy to control oxaliplatin-induced neuropathy. Neuropharmacology 2018, 131, 403-413. [CrossRef] [PubMed]

92. Stieber, J.; Wieland, K.; Stöckl, G.; Ludwig, A.; Hofmann, F. Bradycardic and proarrhythmic properties of sinus node inhibitors. Mol. Pharmacol. 2006, 69, 1328-1337. [CrossRef] [PubMed]

93. Zhang, H.; Dougherty, P.M. Enhanced excitability of primary sensory neurons and altered gene expression of neuronal ion channels in dorsal root ganglion in paclitaxel-induced peripheral neuropathy. Anesthesiology 2014, 120, 1463-1475. [CrossRef] [PubMed]

94. Hagains, C.E.; Senapati, A.K.; Huntington, P.J.; He, J.-W.; Peng, Y.B. Inhibition of spinal cord dorsal horn neuronal activity by electrical stimulation of the cerebellar cortex. J. Neurophysiol. 2011, 106, 2515-2522. [CrossRef] [PubMed]

95. Gold, M.S.; Gebhart, G.F. Nociceptor sensitization in pain pathogenesis. Nat. Med. 2010, 16, 1248-1257. [CrossRef] [PubMed]

96. Kuner, R. Central mechanisms of pathological pain. Nat. Med. 2010, 16, 1258-1266. [CrossRef] [PubMed]

97. Tsantoulas, C.; McMahon, S.B. Opening paths to novel analgesics: The role of potassium channels in chronic pain. Trends Neurosci. 2014, 37, 146-158. [CrossRef] [PubMed]

98. Takasu, K.; Ono, H.; Tanabe, M. Spinal hyperpolarization-activated cyclic nucleotide-gated cation channels at primary afferent terminals contribute to chronic pain. Pain 2010, 151, 87-96. [CrossRef] [PubMed]

99. Sun, Q.; Xing, G.-G.; Tu, H.-Y.; Han, J.-S.; Wan, Y. Inhibition of hyperpolarization-activated current by ZD7288 suppresses ectopic discharges of injured dorsal root ganglion neurons in a rat model of neuropathic pain. Brain Res. 2005, 1032, 63-69. [CrossRef] [PubMed]

100. Cho, H.J.; Staikopoulos, V.; Furness, J.B.; Jennings, E.A. Inflammation-induced increase in hyperpolarization-activated, cyclic nucleotide-gated channel protein in trigeminal ganglion neurons and the effect of buprenorphine. Neuroscience 2009, 162, 453-461. [CrossRef] [PubMed]

101. Ding, W.; You, Z.; Shen, S.; Yang, J.; Lim, G.; Doheny, J.T.; Zhu, S.; Zhang, Y.; Chen, L.; Mao, J. Increased $\mathrm{HCN}$ channel activity in the gasserian ganglion contributes to trigeminal neuropathic pain. J. Pain 2018, 19, 626-634. [CrossRef] [PubMed]

102. Smith, T.; Al Otaibi, M.; Sathish, J.; Djouhri, L. Increased expression of HCN2 channel protein in L4 dorsal root ganglion neurons following axotomy of L5- and inflammation of L4-spinal nerves in rats. Neuroscience 2015, 295, 90-102. [CrossRef] [PubMed]

103. Tibbs, G.R.; Rowley, T.J.; Sanford, R.L.; Herold, K.F.; Proekt, A.; Hemmings, H.C.; Andersen, O.S.; Goldstein, P.A.; Flood, P.D. HCN1 channels as targets for anesthetic and nonanesthetic propofol analogs in the amelioration of mechanical and thermal hyperalgesia in a mouse model of neuropathic pain. J. Pharmacol. Exp. Ther. 2013, 345, 363-373. [CrossRef] [PubMed]

104. Zhang, S.; You, Z.; Wang, S.; Yang, J.; Yang, L.; Sun, Y.; Mi, W.; Yang, L.; McCabe, M.F.; Shen, S.; et al. Neuropeptide $s$ modulates the amygdaloidal $\mathrm{HCN}$ activities $\left(\mathrm{I}_{\mathrm{h}}\right)$ in rats: Implication in chronic pain. Neuropharmacology 2016, 105, 420-433. [CrossRef] [PubMed]

105. Du, L.; Wang, S.J.; Cui, J.; He, W.J.; Ruan, H.Z. Inhibition of HCN channels within the periaqueductal gray attenuates neuropathic pain in rats. Behav. Neurosci. 2013, 127, 325-329. [CrossRef] [PubMed]

106. Cordeiro Matos, S.; Zhang, Z.; Seguela, P. Peripheral neuropathy induces HCN channel dysfunction in pyramidal neurons of the medial prefrontal cortex. J. Neurosci. 2015, 35, 13244-13256. [CrossRef] [PubMed]

107. Noh, S.; Kumar, N.; Bukhanova, N.; Chen, Y.; Stemkowsi, P.L.; Smith, P.A. The heart-rate-reducing agent, ivabradine, reduces mechanical allodynia in a rodent model of neuropathic pain. Eur. J. Pain 2014, 18, 1139-1147. [CrossRef] [PubMed]

108. Surges, R.; Freiman, T.M.; Feuerstein, T.J. Gabapentin increases the hyperpolarization-activated cation current $\mathrm{I}_{\mathrm{h}}$ in rat CA1 pyramidal cells. Epilepsia 2003, 44, 150-156. [CrossRef] [PubMed] 
109. Tae, H.-S.; Smith, K.M.; Phillips, A.M.; Boyle, K.A.; Li, M.; Forster, I.C.; Hatch, R.J.; Richardson, R.; Hughes, D.I.; Graham, B.A.; et al. Gabapentin modulates HCN4 channel voltage-dependence. Front. Pharmacol. 2017, 8. [CrossRef] [PubMed]

110. Postea, O.; Biel, M. Exploring HCN channels as novel drug targets. Nat. Rev. Drug Discov. 2011, 10, 903-914. [CrossRef] [PubMed]

111. Bucchi, A.; Baruscotti, M.; Nardini, M.; Barbuti, A.; Micheloni, S.; Bolognesi, M.; DiFrancesco, D. Identification of the molecular site of ivabradine binding to HCN4 channels. PLoS ONE 2013, 8. [CrossRef] [PubMed]

112. Melchiorre, M.; Del Lungo, M.; Guandalini, L.; Martini, E.; Dei, S.; Manetti, D.; Scapecchi, S.; Teodori, E.; Sartiani, L.; Mugelli, A.; et al. Design, synthesis, and preliminary biological evaluation of new isoform-selective f-current blockers. J. Med. Chem. 2010, 53, 6773-6777. [CrossRef] [PubMed]

113. De Lungo, M.; Melchiorre, M.; Guandalini, L.; Sartiani, L.; Mugelli, A.; Koncz, I.; Szel, T.; Varro, A.; Romanelli, M.N.; Cerbai, E. Novel blockers of hyperpolarization-activated current with isoform selectivity in recombinant cells and native tissue. Br. J. Pharmacol. 2012, 166, 602-616. [CrossRef] [PubMed]

114. McClure, K.J.; Maher, M.; Wu, N.; Chaplan, S.R.; Eckert, W.A.; Lee, D.H.; Wickenden, A.D.; Hermann, M.; Allison, B.; Hawryluk, N.; et al. Discovery of a novel series of selective HCN1 blockers. Bioorg. Med. Chem. Lett. 2011, 21, 5197-5201. [CrossRef] [PubMed]

115. Cheng, L.; Kinard, K.; Rajamani, R.; Sanguinetti, M.C. Molecular mapping of the binding site for a blocker of hyperpolarization-activated, cyclic nucleotide-modulated pacemaker channels. J. Pharmacol. Exp. Ther. 2007, 322, 931-939. [CrossRef] [PubMed]

116. Giorgetti, A.; Carloni, P. Molecular modeling of ion channels: Structural predictions. Curr. Opin. Chem. Biol. 2003, 7, 150-156. [CrossRef]

117. Giorgetti, A.; Carloni, P.; Mistrik, P.; Torre, V. A homology model of the pore region of HCN channels. Biophys. J. 2005, 89, 932-944. [CrossRef] [PubMed]

118. Chan, C.S.; Glajch, K.E.; Gertler, T.S.; Guzman, J.N.; Mercer, J.N.; Lewis, A.S.; Goldberg, A.B.; Tkatch, T.; Shigemoto, R.; Fleming, S.M.; et al. HCN channelopathy in external globus pallidus neurons in models of parkinson's disease. Nat. Neurosci. 2011, 14. [CrossRef] [PubMed]

119. Lewis, A.S.; Chetkovich, D.M. HCN channels in behavior and neurological disease: Too hyper or not active enough? Mol. Cell. Neurosci. 2011, 46, 357-367. [CrossRef] [PubMed]

120. Noam, Y.; Bernard, C.; Baram, T.Z. Towards an integrated view of HCN channel role in epilepsy. Curr. Opin. Neurobiol. 2011, 21, 873-879. [CrossRef] [PubMed]

121. Tu, E.; Waterhouse, L.; Duflou, J.; Bagnall, R.D.; Semsarian, C. Genetic analysis of hyperpolarization-activated cyclic nucleotide-gated cation channels in sudden unexpected death in epilepsy cases. Brain Pathol. 2011, 21, 692-698. [CrossRef] [PubMed]

122. Ludwig, A.; Budde, T.; Stieber, J.; Moosmang, S.; Wahl, C.; Holthoff, K.; Langebartels, A.; Wotjak, C.; Munsch, T.; Zong, X.; et al. Absence epilepsy and sinus dysrhythmia in mice lacking the pacemaker channel HCN2. EMBO J. 2003, 22, 216-224. [CrossRef] [PubMed]

123. Baruscotti, M.; Bucchi, A.; Viscomi, C.; Mandelli, G.; Consalez, G.; Gnecchi-Rusconi, T.; Montano, N.; Casali, K.R.; Micheloni, S.; Barbuti, A.; et al. Deep bradycardia and heart block caused by inducible cardiac-specific knockout of the pacemaker channel gene HCN4. Proc. Natl. Acad. Sci. USA 2011, 108, 1705-1710. [CrossRef] [PubMed]

124. Ramírez, D.; Arévalo, B.; Martínez, G.; Rinné, S.; Sepúlveda, F.V.; Decher, N.; González, W. Side fenestrations provide an "anchor" for a stable binding of A1899 to the pore of Task-1 potassium channels. Mol. Pharm. 2017, 14, 2197-2208. [CrossRef] [PubMed]

125. Ramírez, D. Computational methods applied to rational drug design. Open Med. Chem. J. 2016, 10, 7-20. [CrossRef] [PubMed]

126. Rodríguez, Y.A.; Gutiérrez, M.; Ramírez, D.; Alzate-Morales, J.; Bernal, C.C.; Güiza, F.M.; Romero Bohórquez, A.R. Novel $n$-allyl/propargyl tetrahydroquinolines: Synthesis via three-component cationic imino diels-alder reaction, binding prediction, and evaluation as cholinesterase inhibitors. Chem. Biol. Drug Des. 2016, 88, 498-510. [CrossRef] [PubMed]

127. Rudolph, U.; Antkowiak, B. Molecular and neuronal substrates for general anaesthetics. Nat. Rev. Neurosci. 2004, 5, 709-720. [CrossRef] [PubMed]

128. Franks, N.P. General anaesthesia: From molecular targets to neuronal pathways of sleep and arousal. Nat. Rev. Neurosci. 2008, 9, 370-386. [CrossRef] [PubMed] 
129. Tokimasa, T.; Sugiyama, K.; Akasu, T.; Muteki, T. Volatile anaesthetics inhibit a cyclic AMP-dependent sodium-potassium current in cultured sensory neurones of bullfrog. Br. J. Pharmacol. 1990, 101, 190-192. [CrossRef] [PubMed]

130. Sirois, J.E.; Pancrazio, J.J.; Lynch, C.; Bayliss, D.A. Multiple ionic mechanisms mediate inhibition of rat motoneurones by inhalation anaesthetics. J. Physiol. 1998, 512, 851-862. [CrossRef] [PubMed]

131. Sirois, J.E.; Lynch, C.; Bayliss, D.A. Convergent and reciprocal modulation of a leak $\mathrm{K}^{+}$current and $\mathrm{I}_{\mathrm{h}}$ by an inhalational anaesthetic and neurotransmitters in rat brainstem motoneurones. J. Physiol. 2002, 541, 717-729. [CrossRef] [PubMed]

132. Chen, X.; Sirois, J.E.; Lei, Q.; Talley, E.M.; Lynch, C.; Bayliss, D.A. HCN subunit-specific and cAMP-modulated effects of anesthetics on neuronal pacemaker currents. J. Neurosci. 2005, 25, 5803-5814. [CrossRef] [PubMed]

133. Chen, X.; Shu, S.; Kennedy, D.P.; Willcox, S.C.; Bayliss, D.A. Subunit-specific effects of isoflurane on neuronal $\mathrm{I}_{\mathrm{h}}$ in HCN1 knockout mice. J. Neurophysiol. 2009, 101, 129-140. [CrossRef] [PubMed]

134. Mattusch, C.; Kratzer, S.; Buerge, M.; Kreuzer, M.; Engel, T.; Kopp, C.; Biel, M.; Hammelmann, V.; Ying, S.-W.; Goldstein, P.A.; et al. Impact of hyperpolarization-activated, cyclic nucleotide-gated cation channel type 2 for the xenon-mediated anesthetic effect: Evidence from in vitro and in vivo experiments. Anesthesiology 2015, 122, 1047-1059. [CrossRef] [PubMed]

135. Wan, X.; Mathers, D.A.; Puil, E. Pentobarbital modulates intrinsic and gaba-receptor conductances in thalamocortical inhibition. Neuroscience 2003, 121, 947-958. [CrossRef] [PubMed]

136. Chen, X.; Shu, S.; Bayliss, D.A. HCN1 channel subunits are a molecular substrate for hypnotic actions of ketamine. J. Neurosci. 2009, 29, 600-609. [CrossRef] [PubMed]

137. Zhou, C.; Douglas, J.E.; Kumar, N.N.; Shu, S.; Bayliss, D.A.; Chen, X. Forebrain HCN1 channels contribute to hypnotic actions of ketamine. Anesthesiology 2013, 118, 785-795. [CrossRef] [PubMed]

138. Cacheaux, L.P.; Topf, N.; Tibbs, G.R.; Schaefer, U.R.; Levi, R.; Harrison, N.L.; Abbott, G.W.; Goldstein, P.A. Impairment of hyperpolarization-activated, cyclic nucleotide-gated channel function by the intravenous general anesthetic propofol. J. Pharmacol. Exp. Ther. 2005, 315, 517-525. [CrossRef] [PubMed]

139. Vasilyev, D.V.; Shan, Q.; Lee, Y.; Mayer, S.C.; Bowlby, M.R.; Strassle, B.W.; Kaftan, E.J.; Rogers, K.E.; Dunlop, J. Direct inhibition of $\mathrm{I}_{\mathrm{h}}$ by analgesic loperamide in rat drg neurons. J. Neurophysiol. 2007, 97, 3713-3721. [CrossRef] [PubMed]

140. Lee, Y.T.; Vasilyev, D.V.; Shan, Q.J.; Dunlop, J.; Mayer, S.; Bowlby, M.R. Novel pharmacological activity of loperamide and cp-339,818 on human HCN channels characterized with an automated electrophysiology assay. Eur. J. Pharmacol. 2008, 581, 97-104. [CrossRef] [PubMed]

141. Knaus, A.; Zong, X.; Beetz, N.; Jahns, R.; Lohse, M.J.; Biel, M.; Hein, L. Direct inhibition of cardiac hyperpolarization-activated cyclic nucleotide-gated pacemaker channels by clonidine. Circulation 2007, 115, 872-880. [CrossRef] [PubMed]

142. Carr, D.B.; Andrews, G.D.; Glen, W.B.; Lavin, A. A2-noradrenergic receptors activation enhances excitability and synaptic integration in rat prefrontal cortex pyramidal neurons via inhibition of HCN currents. J. Physiol. 2007, 584, 437-450. [CrossRef] [PubMed]

143. Yang, Y.-C.; Meng, Q.-T.; Pan, X.; Xia, Z.-Y.; Chen, X.-D. Dexmedetomidine produced analgesic effect via inhibition of HCN currents. Eur. J. Pharmacol. 2014, 740, 560-564. [CrossRef] [PubMed]

144. Goldstein, P.A. HCN1 channels as targets for volatile anesthetics: Coming to the fore. Anesth. Analg. 2015, 121, 594-596. [CrossRef] [PubMed]

145. Zhou, C.; Liang, P.; Liu, J.; Ke, B.; Wang, X.; Li, F.; Li, T.; Bayliss, D.A.; Chen, X. HCN1 channels contribute to the effects of amnesia and hypnosis but not immobility of volatile anesthetics. Anesth. Analg. 2015, 121, 661-666. [CrossRef] [PubMed]

146. Zhang, K.; Xu, T.; Yuan, Z.; Wei, Z.; Yamaki, V.N.; Huang, M.; Huganir, R.L.; Cai, X. Essential roles of aMPA receptor GluA1 phosphorylation and presynaptic HCN channels in fast-acting antidepressant responses of ketamine. Sci. Signal. 2016, 9. [CrossRef] [PubMed]

147. Meng, Q.; Xia, Z.; Liu, J.; Bayliss, D.A.; Chen, X. Local anesthetic inhibits hyperpolarization-activated cationic currents. Mol. Pharmacol. 2011, 79, 866-873. [CrossRef] [PubMed]

148. Ye, D.; Wang, J.; Yu, K.; Zhou, Y.; Jiang, H.; Chen, K.; Liu, H. Current strategies for the discovery of $\mathrm{K}^{+}$ channel modulators. Curr. Top. Med. Chem. 2009, 9, 348-361. [CrossRef] [PubMed] 
149. Coburn, C.A.; Luo, Y.; Cui, M.; Wang, J.; Soll, R.; Dong, J.; Hu, B.; Lyon, M.A.; Santarelli, V.P.; Kraus, R.L.; et al. Discovery of a pharmacologically active antagonist of the two-pore-domain potassium channel $\mathrm{K}_{2 \mathrm{p}} 9.1$ (Task[-3). Chem. Med. Chem. 2012, 7, 123-133. [CrossRef] [PubMed]

150. Anderson, A.C. The process of structure-based drug design. Chem. Biol. 2003, 10, 787-797. [CrossRef] [PubMed]

151. Kutzner, C.; Grubmüller, H.; de Groot, B.L.; Zachariae, U. Computational electrophysiology: The molecular dynamics of ion channel permeation and selectivity in atomistic detail. Biophys. J. 2011, 101, 809-817. [CrossRef] [PubMed]

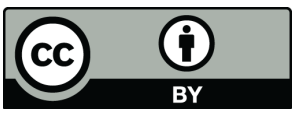

(C) 2018 by the authors. Licensee MDPI, Basel, Switzerland. This article is an open access article distributed under the terms and conditions of the Creative Commons Attribution (CC BY) license (http://creativecommons.org/licenses/by/4.0/). 